Article

\title{
Conceptualizing Testbed Planning: Urban Planning in the Intersection between Experimental and Public Sector Logics
}

\author{
Lina Berglund-Snodgrass ${ }^{1,2}$ and Dalia Mukhtar-Landgren ${ }^{2,3, *}$ \\ ${ }^{1}$ Department of Spatial Planning, Blekinge Institute of Technology, 37179 Karlskrona, Sweden; \\ E-Mail: lina.berglund-snodgrass@bth.se \\ 2 K2-The Swedish Knowledge Centre for Public Transport, 22236 Lund, Sweden \\ ${ }^{3}$ Department of Political Science, Lund University, 22100 Lund, Sweden; E-Mail: dalia.mukhtar-landgren@svet.lu.se \\ * Corresponding author
}

Submitted: 30 September 2019 | Accepted: 17 December 2019 | Published: 13 March 2020

\begin{abstract}
Urban planning is, in many countries, increasingly becoming intertwined with local climate ambitions, investments in urban attractiveness and "smart city" innovation measures. In the intersection between these trends, urban experimentation has developed as a process where actors are granted action space to test innovations in a collaborative setting. One arena for urban experimentation is urban testbeds. Testbeds are sites of urban development, in which experimentation constitutes an integral part of planning and developing the area. This article introduces the notion of testbed planning as a way to conceptualize planning processes in delimited sites where planning is combined with processes of urban experimentation. We define testbed planning as a multi-actor, collaborative planning process in a delimited area, with the ambition to generate and disseminate learning while simultaneously developing the site. The aim of this article is to explore processes of testbed planning with regard to the role of urban planners. Using an institutional logics perspective we conceptualize planners as navigating between a public sector-and an experimental logic. The public sector logic constitutes the formal structure of "traditional" urban planning, and the experimental logic a collaborative and testing governance structure. Using examples from three Nordic municipalities, this article explores planning roles in experiments with autonomous buses in testbeds. The analysis shows that planners negotiate these logics in three different ways, combining and merging them, separating and moving between them or acting within a conflictual process where the public sector logic dominates.
\end{abstract}

\section{Keywords}

experimental governance; institutional logics; urban experimentation; urban planning; testbed planning

\section{Issue}

This article is part of the issue "Urban Planning and the Smart City: Projects, Practices and Politics" edited by Andrew Karvonen (KTH Royal Institute of Technology, Sweden), Matthew Cook (Open University, UK) and Håvard Haarstad (University of Bergen, Norway).

(C) 2020 by the authors; licensee Cogitatio (Lisbon, Portugal). This article is licensed under a Creative Commons Attribution 4.0 International License (CC BY).

\section{Introduction}

Urban planning is, in many countries, increasingly intertwined with local climate ambitions, including expectations on municipalities to implement sustainability goals (Davidson \& Gleeson, 2018). In addition, cities are investing in urban attractiveness, such as brownfield development, place marketing and "smart city" innovation measures. In the intersection between these trends, urban experimentation has developed as a means for finding solutions to urban challenges (cf. Evans \& Karvonen, 2014; Haarstad, 2017; Raven et al., 2019) as well as promoting national innovation. Urban experimentation can take the forms of urban living labs, pilot projects and testbeds, which all constitute processes where actors are granted space to develop and/or test innova- 
tions, often in collaborative settings (Menny, Voytenko Palgan, \& McCormick, 2018; Mukhtar-Landgren, Kronsell, Voytenko Palgan, \& von Wirth, 2019). Experiments are conducted in a range of areas from transport to energy efficient housing, with the common goal of sharing knowledge to facilitate policy learning, including scaling up and disseminating results with the ambition to generate system change (von Wirth, Fuenfschilling, Frantzekaki, \& Coenen, 2019).

In the urban setting, experimentation can be said to constitute both an approach to sustainability and an arena, eg. an institutional and geographical bound space (Voytenko Palgan, McCormick, \& Evans, 2018). One example of the latter is the urban testbed, which we here define as a geographically delimited site of urban development, in which urban experiments constitute an integral part of planning and developing the area (cf. Calvillo, Halpern, LeCavalier, \& Pietch, 2015; Eneqvist \& Karvonen, 2019), which often-but not exclusively-are situated in centrally located industrial areas (brownfield sites) or in areas with little or no previous development (greenfield sites). These sites are often promoted and labelled as "innovative" or "smart," and through such a status are seen as separate from their immediate surrounding (Burton, Karvonen, \& Caprotti, 2019). Labelling urban development districts as "smart" constitutes a popular practice among policy makers and others involved at trying to gather entrepreneurial initiatives connected to ICT developments and mainstream these developments within the fabric of the city (Raven et al., 2019), but also among those who seeks to accelerate innovations for the transition to sustainability (Haarstad, 2017). The notion of "smart city" constitutes a powerful rhetorical and legitimating device for catalysing and lending coherence to such a variety of practices (Cowley \& Caprotti, 2019), but "smart" is also promoted as an ethos for managing and governing cities of the future (Karvonen, Cugurullo, \& Caprotti, 2019).

In the Nordic countries, experimentation is increasingly employed in development processes on these testbed sites. One possible reason for this is the incidence of external (including state) funding for experimentation. Another is the interest from companies to develop products, such as autonomous vehicles, in "real life settings" (Berglund-Snodgrass, Mukhtar-Landgren, \& Paulsson, 2019). In essence, the development of testbed areas is carried out through parallel processes of urban planning and experimentation, which can be said to be permeated by two different institutional logics-a public sector logic and an experimental logic.

The aim of this article is to explore processes of testbed planning with regard to the role of urban planners in the intersection between urban planning and experimentation. We define testbed planning as a multiactor, collaborative planning process in a geographically delimited area, with the ambition to generate and disseminate learning while simultaneously developing the site.
A small but growing literature is exploring the relationships and tensions between traditional urban planning and newer processes of urban development. In this context, Agger and Sørensen (2018) have analyzed tensions in planning roles in relation to processes of collaborative innovation in urban planning. Other studies include the relationship between urban planning and smart city development (Cowley \& Caprotti, 2019) and urban governance experiments (Davidson \& Gleeson, 2018). The role of public actors has also been analyzed beyond urban planning, including the role of municipalities in urban experimentation in a broader sense (e.g., Castán Broto \& Bulkeley, 2014; Kronsell \& MukhtarLandgren, 2018). One aspect that has been highlighted in this context is the emergence of new roles for municipal civil servants (Makkonen, Merisalo, \& Inkinen, 2018), including new intermediating roles (Hakkarainen \& Hyysalo, 2016). Yet, research has also shown that the traditional roles that permeate public administration persist alongside these new roles (cf. Karvonen, Evans, \& van Heur, 2014). The extent to which urban experimentation more specifically contributes to influencing and shaping the traditional planning role is less explored, and it is here that this article sets out to make its contribution. The next section delineates the institutional logics perspective and the two logics that are set center stage for analysis, thereafter we describe the material and the methods applied.

\section{Testbed Planning Set within Public Sector and Experimental Logics}

The notion of institutional logics has been developed in neo-institutional theory where institutions are understood as including not only formal, but also informal aspects such as roles, identities and norms (March \& Olsen, 2013). Institutional logics is a way to analyze the different beliefs and practices that shape how individuals act (Thornton \& Ocasio, 2008, p. 101). They are seen as "organizing principles" which provide "social actors with vocabularies of motive and a sense of self (i.e., identity)" (Thornton \& Ocasio, 2008, p. 101). The core of the concept is the link between individual action and understandings of "appropriate and legitimate behavior" (Fred, 2018, p. 35; cf. Thornton \& Ocasio, 2008). Here, we use logics as ideal types, and analyze how planners relate to and negotiate between them in testbed planning processes. Below, we outline a framework for analyzing processes of testbed planning, based on two logics-a public sector logic intrinsic to "traditional urban planning" and an experimental logic intrinsic to "urban experimentation." We have set out five differences and points of negotiations between them. These are problem representations, means for goal attainment, governing tools, relation to stakeholders and priorities. The logics, and these points of negotiation, are based in previous discussions and categorisations on public sector and institutional logics in flux (e.g., Agger \& Sørensen, 2018; 
Bryson, Crosby, \& Bloomberg, 2014), as well as in literature on experimental governance. The two logics will be described below.

\subsection{The Public Sector Logic}

The public sector logic is here understood as the formal governance structure of "traditional" urban planning, where the legitimacy of municipalities, as part of government, rests on its democratic and bureaucratic function. Democratic legitimacy more specifically relates both to the representative function of municipalities with an emphasis on input-legitimacy (such as democratic accountability), but also concerns output legitimacy (relating to implementation capacity and results; Kronsell \& Mukhtar-Landgren, 2018). Planners, in their formal capacity, thus act as parts of a bureaucratic and political organisation configured to ensure the delivery of political objectives while taking account of public values. For urban planners, public values are comprised by both professional norms residing within all public professions (such as medical professions, the police force, teachers and urban planners), but also more general bureaucratic norms common for all professions including procedural values such as accountability, legality, impartiality and rule of law (cf. Hysing \& Olsson, 2012; Lundquist, 1988; Svara, 2006). Acting within the frame of public administration, of which urban planning is a part, "is thus primarily about meeting the demands of official, not individual, personal responsibility and accountability" (du Gay, 2017, p. 158). The fact that urban planning represents a decision making body and in that way has to sustain democratic legitimacy, makes it inherently different from other participating actors in these test-bed planning collaborations.

The first category used to analyze negotiations between the two logics is problem representations, i.e., the question of which type of problems are in focus. Traditional urban planning is generally understood as being organized to respond to a set of societal conditions prominent in the 20th century, including industrialization, rapid urbanization and a strong belief in progress (Bryson et al., 2014). In a post-industrial context, these ideals are further connected to urban entrepreneurialism and an understanding of urban growth as related to an inter-urban competition between cities on a global market (Hall \& Hubbard, 1998; Harvey, 1989). The second category concerns how public actors reach policy goals, or their means for goal attainment. Planning goals are determined by political electives and the means are determined, organized and delivered through a hierarchical bureaucratic system (Agger \& Sørensen, 2018). This relates to the third category, governing tools, which here includes bureaucratic routines such as formal legislation and regulations (Allbrecht, 2004). The fourth category is the relation to stakeholders. In a public sector logic, authority is distributed hierarchically (Agger \& Sørensen, 2018), and planners balance private and public interests through bargaining and negotiating with stakeholders and placing demands on private actors through legislation (cf. Nadin, 2007). When operating according to this logic, the priorities (the fifth category) are to maintain order, control and stability (Agger \& Sørensen, 2018). One important aspect is the importance of long-term planning solutions based on knowledge, i.e., what we comprehensively know and can predict and foresee in the future (cf. Rydin, 2007).

\subsection{The Experimental Logic}

The experimental logic is instead characterized by the collaborative, testing, learning and innovative structure of urban experimentation. In essence, this logic is permeated by an implicit critique directed towards traditional urban planning, suggesting that there is a need to go beyond "business as usual" and find new solutions. This can include assumptions of traditional urban planning as being path-dependent and plagued by organizational inertia-and consequently in need of renewal (cf. Carroli, 2018). This can also be related to an overall discourse on "wicked problems" i.e., the widespread notion that today's societal problems are so difficult that they require new forms of governance to be solved (cf. Bryson et al., 2014, p. 447). This is also one of the problem representations within urban experimentation, which is configured to respond to another set of societal conditions such as neoliberalism and austerity (Bryson et al., 2014). In accordance, the means for goal attainment include opening up processes for a plethora of actors in the attainment of public goals, where planners facilitate service delivery through governing tools related to various forms of enabling, such as facilitating (Mukhtar-Landgren et al., 2019). Facilitating is referred to here as "providing opportunities to other people, by educating, gathering and distributing resources, influencing regulations, developing the local rules, and creating "spaces" for others to act" (Hakkarainen \& Hyysalo, 2016, p. 47). Central to this logic is that authority is seen as distributed horizontally (Agger \& Sørensen, 2018) which impacts the planners' relation to stakeholders. They engage in "coproducing" activities with private actors and other stakeholders rather than regulating them (cf. Voytenko Palgan et al., 2018). Priorities are testing, creativity and (radical) change rather than maintaining order and upholding stability (Agger \& Sørensen, 2018). Finally, we recognize that several characteristics of experimentation, such as co-producing of knowledge and the incidence of horizontal networks and dialogues, have been intrinsic to other planning ideals over time, including both advocacy planning (Davidoff, 1965) and communicative planning ideals (cf. Forester, 1989). In addition, it is important to also point out that several of the more current trends described above are not exclusive for urban experimentation: Urban planning has, at large, experienced significant changes during the last decades (Olesen \& Richardson, 2012; cf. Healey, 1997). This includes the introduction of more strategic means of inte- 
grating and coordinating spatial policies across sectors, including the increasing incidence of stakeholder collaborations (Allmendinger \& Haughton, 2009; Allmendinger, Haughton, \& Shepard, 2016; Nadin, 2007), entailing that the collaborative settings intrinsic to urban experimentation are not exclusive for experimentation. In addition, it has been pointed out that urban planning carried out within such informal planning arenas are, to an increasing extent, shaping formal planning processes (cf. Olesen, 2014). Instead, and to sum up, the ideal typical characteristics outlined above are analytical constructs; they are not exhaustive or mutually exclusive. They function to elevate fundamental aspects of the different logics for illuminating how urban planning balance these in testbed planning processes. The logics are summarized in Table 1.

\section{Method and Empirical Material}

This article draws from an in-depth multiple-case study (cf. Yin, 2014) which allows for the investigation of testbed planning processes across multiple settings, and through this, gain a deeper understanding of how such processes are enacted in the intersection between the different logics. We are specifically interested in identifying common insights of test bed planning across cases rather than comparing and identifying differences. The cases are selected from Nordic countries that all share a similar tradition of a decentralized state and strong local autonomy (Loughlin, 2000). The Nordic planning systems can be described as being characterized by a comprehensive planning model and urban planning constitutes primarily a municipal affair (Fredricsson \& Smas, 2015). Since we are interested in testbed planning, we have strategically chosen three cases of such processes in three Nordic municipalities. To be seen as examples of testbed planning, the cases should comprise an ongoing urban experiment in a geographically delimited testbed site. As outlined in the introduction, we define a testbed as a delimited geographical site of urban development, in which experiments constitute an integral part of planning and developing the area. The testbed planning processes in the three cases consists of experi- ments with smart mobility solutions (autonomous buses in so called "real world settings") in delimited testbed sites. The testbed sites are labelled by the municipalities as "smart city districts" or "innovation sites" for sustainable development. As we are particularly interested in the role of urban planners in these testbed planning processes, we have conducted interviews with two main types of actors: (1) municipal actors such as urban and transport planners, development managers, coordinators and engineers, and (2) intermediary actors such as project managers. We define an intermediary actor as "[a]n organization or body [or an individual] that acts as an agent or broker in any aspect of the innovation process between two or more parties" (Howell, 2006, as cited in Hakkarainen \& Hyysalo, 2016, p. 46). The intermediaries are seen as "operating between different social interests (and technologies) to produce outcomes that would not have been possible without their involvement" (Marvin, Bulkley, Mai, McCormick, \& Voytenko Palgan, 2018). In all three cases, the intermediary actors are situated in partnership organisations-between the municipality(ies) and private actors. The partnership organisation operates within the overall objective to jointly develop smart and sustainable urban solutions.

The empirical material as a whole consists of policy documents as well as fifteen semi-structured interviews with these two main types of actors. The interviews were carried out between September 2018 and February 2019 and concerned the different actors' perceived roles, tasks and duties and their overall contributions in the testbed planning processes. The interviewees were also asked to reflect on the connection between the urban experiments and the everyday planning processes.

We use ideal types as an analytical method for analyzing how planners navigate their different roles in testbed planning. Using ideal types is theoretically driven and the categories on the " $x$ " and " $y$ "-axis emanate from the established literature (cf. Reay \& Jones, 2016). The analysis was carried out in two steps. First, we identified the five categories as stipulated in Table 1 in the empirical material. We specifically focused on how these five aspects

Table 1. Five points of negotiations in testbed planning.

\begin{tabular}{lll}
\hline & Public sector logic & Experimental logic \\
\hline $\begin{array}{lll}\text { Problem } \\
\text { representations }\end{array}$ & $\begin{array}{l}\text { Industrialism, (post-industrialism), urbanization, } \\
\text { progress, modernism, inter-urban competition }\end{array}$ & $\begin{array}{l}\text { "Wicked problems," “hollowing the state," } \\
\text { neoliberalism }\end{array}$ \\
\hline $\begin{array}{l}\text { Means for goal } \\
\text { attainment }\end{array}$ & $\begin{array}{l}\text { Hierarchical organizations, formal decision } \\
\text { making procedures }\end{array}$ & $\begin{array}{l}\text { Enabling service delivery from different } \\
\text { providers }\end{array}$ \\
\hline $\begin{array}{l}\text { Relation to } \\
\text { stakeholders }\end{array}$ & Balancing between private and public interests & $\begin{array}{l}\text { Co-creating solutions with private and public } \\
\text { stakeholders }\end{array}$ \\
\hline Governing tools & Regulating including legislation & Enabling (facilitation, visioning, collaboration) \\
\hline $\begin{array}{l}\text { Priority (from Agger } \\
\text { \& Sørensen, 2018) }\end{array}$ & Order, predictability, control and stability & Creativity, testing and experimentation \\
\hline
\end{tabular}


were managed in the development processes with specific regard to urban planners, and the material was organized using them as our point of departure. Second, we analyzed the material in relation to how urban planners negotiated between them. Below, we briefly summarize the results of the analysis, and thereafter we give three examples of negotiations from our material.

\section{Summary of Results}

The results of the analysis (summarized in Table 2) illustrate the incidence of both logics. In relation to problem formulations, the experimental logic was visible in the emphasis on the need to go beyond "business as usual," and the public sector logic shone through in the emphasis on post-industrial problematizations relating to branding and inter-urban competition. It appears as there is no tension between the logics, instead public actors combine and reconcile them in their reasoning around urban experimentation in testbed planning. This form of negotiation was also evident in relation to stakeholders: Even though there is a tradition in urban planning to negotiate with private actors and developers, the "new" role of co-creating solutions was not approached as conflictual but possible to combine with traditional planning practices. In relation to the means for goal attainment, there was neither a tension-nor was there any apparent will to combine the different logics' means of service delivery. Even though urban experiments were generally described as something completely different from traditional planning processes, urban planners managed to separate yet move between them without reconciling them, somehow wanting to separate "real" planning from new processes of urban development, without seeing them as conflictual. This way of navigating also characterized their relation to governing tools. Urban planners moved between the referring to formal planning tools (regulations, etc.) and their role in providing opportunities for external actors. Finally, when it comes to priorities in urban planning, the logics are emphasized as rivalry. Testing and risk taking, central dimensions of urban experimentation, open up a conceptual space of failing, which don't resonate well with notions of order, predictability and stability that characterize traditional urban planning. Summing up, there is a variation in how well urban experimentation "fits" the public logic of urban planning; there is sometimes a perceived need to separate what planners "do" in relation to new innovative trends, but in other cases, differences in problematizations and approaches are reconciled. Sometimes this movement appears without friction, and sometimes it appears more conflictual. To conclude, we identify three different ways in which urban planners navigate between the two logics: They (1) combine and reconcile them, they (2) separate yet move between them, and finally (3) they emphasize rivalry positions. In the following section we will analyze these negotiations further by providing examples from the empirical material.

\section{Analysis: Negotiating between Logics in Testbed Planning}

In this section, we analyze negotiations between the public sector-and experimental logics in processes of testbed planning with specific regard to urban planners. The first example is how urban planners combine and reconcile the logics, which we illustrate in relation to their handling of problem representations.

\subsection{Combining and Reconciling: Responding to "Wicked" Sustainability Problems whilst Contributing to Progress}

Our analysis showed that the problem representations inherent to the different logics, the traditional problem

Table 2. Public sector and experimental logics in three examples of testbed planning.

\begin{tabular}{llll}
\hline & Public sector logic & Experimental logic & \multicolumn{1}{l}{$\begin{array}{l}\text { How city planners navigate } \\
\text { between the logics }\end{array}$} \\
$\begin{array}{llll}\text { Problem } \\
\text { representations }\end{array}$ & $\begin{array}{l}\text { Emphasis on post-industrialism, } \\
\text { urbanization, progress as related } \\
\text { to innovation. Focus on branding } \\
\text { relating to inter-urban competition. }\end{array}$ & $\begin{array}{l}\text { Strong emphasis on } \\
\text { "wicked problems" }\end{array}$ & $\begin{array}{l}\text { Urban planners combine and } \\
\text { merge the two logics }\end{array}$ \\
\hline $\begin{array}{l}\text { Means for goal } \\
\text { attainment }\end{array}$ & Hierarchical organizations & $\begin{array}{l}\text { Enabling service delivery } \\
\text { from different providers }\end{array}$ & $\begin{array}{l}\text { Urban planners move } \\
\text { unproblematically between } \\
\text { the two logics }\end{array}$ \\
\hline $\begin{array}{l}\text { Relation to } \\
\text { stakeholders }\end{array}$ & Balancing between private & Co-creating solutions with & Urban planners combine and \\
Governing tools public interests & Regulating incl. legislation & Enabling (facilitation, & Urban planners move \\
& & visioning, collaboration) & $\begin{array}{l}\text { unproblematically between } \\
\text { the two logics }\end{array}$ \\
\hline Priority & Order, control and stability & $\begin{array}{l}\text { Creativity, } \\
\text { experimentation and change }\end{array}$ & $\begin{array}{l}\text { Conflicting logics. public } \\
\text { sector logic dominates }\end{array}$ \\
\hline
\end{tabular}


representations related to progress and modernism in the post-industrial city, and problem representations related to "wicked problems," are combined and reconciled in testbed planning processes. In practice this entails a new and powerful discourse of smart and sustainable urban development which contributes to urban progress, both in an economic and scientific sense. The importance of branding urban development districts is repeatedly mentioned by the municipal actors as a key dimension for why they choose to participate in processes of urban experimentation. Experimentation with smart technology is brought forward as having the capacity to attract investments to the testbed-site, and through this contribute to deliver the overarching municipal visions for the development of the districts. One project manager formulates the branding exercise through experimentation like this:

The shuttles, as we see it, are really important because they can deliver many things, they can not only deliver this first last mile to and from the light rail way, they also have the ability to somehow brand the area as something new, and they potentially can facilitate the transport itself in the area....So the municipality is working with a master plan for the area, it's close to [a major city], so it's attractively placed, it's close to the light rail, it has education institutions, and it is close to beautiful green areas, so there are a lot of elements that make this an attractive area. How can the municipality use these elements and the driverless shuttle as a first last mile solution, how in that combination can they help the municipality attract investors to realize the vision for this area? (Project manager 1)

The quotation illustrates how different ideas are merged and reconciled, and problems solved through testbed planning processes. Testbed planning is construed as responding to a "wicked" sustainable-mobility problem (experimenting with solutions for the "first mile/last mile problem") whilst simultaneously responding to expectations of economic progress by regenerating and "branding" the city, attracting investors and increasing municipal revenue. Partaking in urban experiments and enabling the advancement of technology constitute prerequisites (or a necessary evil) for being able to brand and promote the urban development districts. Enabling technological progress is sometimes framed by the planners as a societal good in its own right, arguing that "if we are not putting our roads at their service, we might not go anywhere with autonomous mobility" (Interview, Transport planner 1). Summing up, urban planners in testbed planning manage to reconcile the problem representations inherent to the different logics on a discursive and rhetorical level, through the powerful legitimating principle of smart and sustainable urban development. Through such a discursive and rhetorical reconciliation of ideas, the urban planners provide a way for the logics to be merged rather than appear as competing.

\subsection{Moving between Separated Positions: Regulating and Enabling}

Another way of negotiating between the logics was the tendency to separate and move between them. To illustrate this point, we use the category governing tools. In testbed planning, urban planners regulate experiments in the statutory aspects of planning (e.g., granting building and/or road permissions) as well as enable experimental and collaborative activities in various ways such as participating in workshops and meetings. The different logics act to separately guide the planners in their different tasks as the activities are conceptualized as two separate entities that are not mutually exclusive. Planners thus manage to unproblematically move between the logics, where "new" governing tools related to urban experimentation seem unproblematic to combine with (rather than replace) more traditional planning instruments. As mentioned in the literature overview on urban experimentation, public officials are repeatedly understood as key enablers in experimental processes, as one respondent states: "they [urban planners] are what we have, they are what we offer" (Interview, Intermediating actor 1). One important actor in this context is the intermediary, which we defined above as an "[a]n organization or body [or an individual] that acts an agent or broker in any aspect of the innovation process between two or more parties" (Howell, 2006, in Hakkarainen \& Hyysalo, 2016, p. 46). The intermediary actor wants to offer an easy process with the municipality to the private actors by, for example, asking the municipal actors to smoothly grant necessary permissions for the experiment to take place. One intermediary actor formulates it almost as their duty: "[we offer] a smooth process with the municipality" (Interview, intermediary actor 2). Having the civil servants on board in experiments is recognized as key by the intermediaries as they need to be legally and regulatorly endorsed. Urban planners are being encouraged to partake and facilitate urban experimentation by the intermediary organizations as well as by high level leadership within the municipal organizations, often with initiative from the politicians. One project manager formulates it like this:

They are kind of the, enabler, I would say, it's very crucial to have their blessing on everything we do, because otherwise, if it's not there, then it won't happen....But then, I think, many of the departments in the city, they are maybe not looking forward [to participating] that much, so I think it's really important that you kind of get people excited about these new things, get them committed to these new things. (Project manager 3)

As mentioned above, it is not only the intermediary actors who are pushing for the introduction of these governing tools within the public administration. High level leadership within the municipality is also brought for- 
ward (as per project manager 2). One high level leadership strategy for introducing new sets of governing tools within the public administration took the form of launching a competition between civil servants:

We work very closely with the project manager to see where the bus could go in 2020.... Last year, last spring, we had this competition...our manager told us now we want to test more of these buses. And every person working here, like ok, make your own plan where the bus might go. I think the winner got like 1000 euros or so? (Transport planner 2)

Launching a competition constitutes a significant quest for opening up new governing tools within the local government. We interpret that the competition and its associated tasks are not introduced as activities that are contradictory to, or can be merged with the urban planners' other tasks, but as something new and complementary, and thus conceived as separated and can be "added on."

Yet there is a clear separation between tools, and some are skeptical about endorsing and facilitating urban experiments in the hunt for municipal competitiveness. Here, they raise the point that municipalities must become better at prioritizing between experiments in relation to local goals (as per the municipal smart city coordinator and transport planner 2). One respondent formulates it like this:

I see that in a lot of places, we just do it because companies come along and [say] "hey, do you want to test it" and "yeah, let's do that," and I don't think that is good for us in the long run, I, rather that we say [that we do] projects based on needs, either the citizens' needs or the people working here, that they have a need to do things better. (Municipal smart city coordinator)

In the quotation above we can identify tendencies of resistance towards this "push" for facilitating urban experiments. We interpret from our interviews that many civil servants believe that municipalities at large need to become better at conditioning their participation in urban experiments, and better at prioritizing between and regulating experiments, and thereby place demands on actors in such processes.

Summing up, urban planners engaged in testbed planning processes use governing tools from both of the logics, and opt to both regulate and enable experimental activities, and manage to move between the logics by conceptualizing them as separate activities that are not mutually exclusive. Regulating remains a core public sector governing tool but various enabling activities are simply added to the repertoire of tools among urban planners, albeit with varying degrees of skepticism amongst public actors.

\subsection{Emphasizing Rivalry Positions: Not Compromising on Taking Risks}

One example where the logics are emphasized as rivalry is the negotiation of priorities. The conflicting positions are brought forward in antagonistic terms which can't be compromised. Planners appear not to compromise on matters such as stability and long-term goals for the development district. These conflicting priorities are discussed by one respondent:

On the one hand, there is an approach of being open and saying, ok, we are very interested in learning how to apply autonomous vehicles into our masterplan, city planning, and on the other hand, there is an approach saying, we don't see that this is possible, how can we do with traffic and we don't even know what kind of criteria to set up when we are going to develop, and this is too narrow lane, and there are too many trees, and what about this parking area here, so until we start the concretization of the tools and saying, now we have the test and we can see that this is possible, and this is not possible, and this is not a good idea, I think there is a tendency that the practical barriers are somehow very realistic barriers. (Project manager 1)

The quotation highlights that urban planners are conflicted between their role in participating in processes of urban experiments with a lot of uncertainties and their role in contributing to the provision of long-term planning solutions based on what they comprehensively know and can predict and foresee in the future (cf. Rydin, 2007), including the upholding of responsible public spending. Prioritizing urban experimentation is conceived as including too many unknowns for urban planners to justify. These conflicting priorities thereby affect their commitment to the urban experiment, where there is a tendency that urban planners choose to return to "traditional" comprehensive strategies when developing the testbed site. Others reinforce their own expert knowledge of how to develop the area:

You have to understand that, when we decide to make a street somewhere and build houses around it, it is kind of a decision for 200 years, and where we have the smart city solutions, they come and go. The city structure has to be so that you actually can bring this electric car charging thing there and you can take it off also...think Champs Elysée, how the parades have gone through there, there has been Napoleon, there has been Hitler, there has been Sarkozy. I don't find any difficulty, any controversial thing, that [the smart district] starts at some point and it will end at some point also, maybe not in a hundred years, but at some point. (Urban planner 2) 
What is suggested in the quotation above is that urban planning is an activity with long term objectives which exceeds the scope and priorities of urban experiments. The uncertainties that are coupled with the short term objectives of the experiments are thus not reconciled nor merged into the long-term goals of urban planning, instead a return to "business as usual" dominate: "we need to plan the area as we thought we would, and then hopefully the technology will adjust" (Interview, Municipal smart city coordinator). The urban experiments thus bring about a new emphasis in urban planning processes by its focus on understanding and responding to shortterm problems in the city, which challenge the very idea of comprehensive urban planning and securing longterm goals (cf. Cowley \& Caprotti, 2019). However, the urban planners in our empirical material were not ready to include this new short-term emphasis in their professional identity.

Summing up, negotiating priorities in testbed planning constitutes one example of a point of contestation between the logics, where the different priorities can't be neatly reconciled nor used to complement each other.

\section{Conclusion: Testbed Planning}

This article introduces the notion of testbed planning as a way to conceptualize planning processes in delimited sites where planning is combined with processes of urban experimentation. The question of how and to what extent urban experimentation contributes to influence and shape the traditional urban planning role is placed center stage in our analysis. Our point of departure is a neo-institutional perspective where actors, in our case urban planners, are embedded in institutional logics that provide provide them with a vocabulary, selfidentity and motifs (Thornton \& Ocasio, 2008). The analysis reveals that urban planners are based in a public sector logic, they see themselves as representatives of a profession (planners), inscribed in a trajectory of previous planning processes, and upholding the public good. They also see themselves as representatives of the formal bureaucratic planning administrations and offices by which they were employed. This entails that they also operate within beliefs and routines that shape the ways in which they engage in planning processes, which in turn guide what they deem appropriate behavior.

The analysis also shows that urban planners are open to including new aspects to their role as planners. But interestingly enough, it is primarily on a discursive or ideational level that they are able to include, combine and reconcile ideas of urban experimentation: here ideas of smart city development and innovation seem to fit into the current practices of attractive and sustainable cities. In relation to urban progress, there is an image that experimentation can be reconciled with modernity, rationality and (sustainable) development in ways that resonate with the vocabulary and self-identity of urban planners. Even though they refer to the "smart city" more as a trend (rather than an all-encompassing vision), they manage to reconcile it with a powerful notion of future cities which helps "make sense" of the processes of testbed planning.

When it comes to more concrete practices as the means for goal attainment and governing tools, there is a clear separation between traditional urban planning processes within the formal bureaucratic organization, and the newer soft governing tools of enabling. These new tools are something that urban planners can simply add on to their responsibilities, yet there is a clear need to separate the two tasks from each other, always falling back to the reality of everyday planning where issues such as regulations or safety requirements constitute the core of "real" planning processes. Smart city development as a way of working is seen more as a temporary trend, existing maybe primarily as an overarching idea, not as a process that challenges traditional planning tools in any fundamental sense (even though that is in fact often the goal with urban experimentation!). This tendency brought about frustrations among intermediary actors in municipalities, as their aim was to encourage planners to open up their processes to innovation.

Finally, there is one part of the public ethos and identity of urban planners that is not negotiable, and that is the emphasis on maintaining order, control and stability in urban development. Here a pivotal aspect is the importance of long-term planning solutions based on knowledge. In this context, the urban experiment is perceived of as a short term solution that may be carried out during a limited period of time, but is not based in the tradition of urban planning experience and knowledge on urban development narrated through education, a shared sense of how knowledge is acquired, competencies in the planning communities, and past experiences. The notion on long-term planning is thus a public sector logic that is difficult to reconcile with the notion of testing and risk-taking that characterizes urban experimentation.

Summing up, urban planners in testbed planning processes are influenced by urban experimentation, but primarily on a discursive level, and with a maintained skepticism to altering priorities and ways of working in any fundamental way. Instead of seeing new roles amongst urban planners, we noted that the characteristics associated with an experimental logic instead seemed to have materialized amongst the emerging intermediary actors. These are actors that have entered the context of local governments through processes of urban experimentation. Intermediary actors, who not so seldom have a background in entrepreneurial undertakings, have a tendency to identify themselves as private actors, or as consultants or project leaders (rather than public servants). Looking forward, a question-that requires and merits further research-is if these actors are to same extent embedded in public sector values, as they are not members of a clear profession (such as the planning profession), nor can they be expected to adhere to the more 
general bureaucratic norms mentioned above, as they do not perceive themselves primarily as bureaucrats. In line with previous calls for critical engagement with the underlying politics, narratives and ideals permeating urban experimentation (Caprotti \& Cowley, 2017; Kronsell \& Mukhtar-Landgren, 2018), including pitfalls in relation to democratic legitimacy (Davidson \& Gleeson, 2018), this analysis opens up to questions related to the actors and roles included and recreated through processes of urban experimentation. As noted by Cowley and Caprotti (2019, p. 429), experimental governance may have "unsettling effects on urban planning" which in turn "invites ongoing critical attention in future." In line with this line of reasoning, the introduction of new types of actors (moving in-between public and private sector logics) in local governments through testbed planning may thus have a profound impact on the long term democratic legitimacy of urban planning and could contribute to a possibly marginalized role for urban planners (reduced to mere implementers of planning and building regulations). The entry of new intermediary actors in urban planning process thus constitutes an important aspect for further research, not least in relation to (changes of democratic) values and norms within the local government.

\section{Acknowledgments}

The article was written within the frame of a research project funded by K2-The Swedish Knowledge Centre for Public Transport. Thank you to the anonymous reviewers for valuable comments, and to the civil servants and other actors that took their time to participate in the interviews.

\section{Conflict of Interests}

The authors declare no conflict of interests.

\section{References}

Agger, A., \& Sørensen, E. (2018). Managing collaborative innovation in public bureaucracies. Planning Theory, 17(1), 53-73.

Allbrecht, L. (2004). Strategic (spatial) planning reexamined. Environment and Planning B: Urban Analytics and City Science, 31(5), 743-758.

Allmendinger, P., \& Haughton, G. (2009). Soft spaces, fuzzy boundaries, and metagovernance: The new spatial planning in the Thames Gateway. Environment and Planning A, 41, 617-633.

Allmendinger, P., Haughton, G., \& Shepard, E. (2016). Where is planning to be found? Material practices and the multiple spaces of planning. Environment and Planning C: Government and Policy, 34(1), 38-51.

Berglund-Snodgrass, L., Mukhtar-Landgren, D., \& Paulsson, A. (2019). Experiment för hållbar mobilitet. Vad innoveras det (inte) kring i svenska kommuner? [Ex- periment for sustainable mobility: What are Swedish municipalites (not) innovating about?]. In J. Algehed, E. Eneqvist, C. Jensen, \& J. Lööf (Eds.), Stadsutveckling: En forskningsantologi om organiseringsutmaningar för stad och kommun [Urban development: A research anthology about organisational challenges] (pp. 89-112). Gothenburg: Mistra Urban Futures.

Bryson, J. M., Crosby, B. C., \& Bloomberg, L. (2014). Public value governance: Moving beyond traditional public administration and the new public management. Public Administration Review, 74(4), 445-456.

Burton, K., Karvonen, A., \& Caprotti, F. (2019). Smart goes green. Digitialising environmental agendas in Bristol and Manchester. In A. Karvonen, F. Cugurullo, \& F. Caprotti (Eds.), Inside smart cities. Place, politics and urban innovation (pp. 117-132). London and New York, NY: Routledge.

Calvillo, N., Halpern, O., LeCavalier, J., \& Pietch, W. (2015). Test bed as urban epistemology. In S. Marvin, A. Lucque-Ayala, \& C. McFarlane (Eds.), Smart urbanism: Utopian vision or false dawn (pp. 181-206). London and New York, NY: Routledge.

Caprotti, F., \& Cowley, R. (2017). Interrogating urban experiments. Urban Geography, 38(9), 1441-1450.

Carroli, L. (2018). Planning roles in infrastructure system transitions: A review of research bridging sociotechnical transitions and planning. Environmental Innovation and Societal Transitions, 29, 81-89.

Castán Broto, V., \& Bulkeley, H. (2014). Maintaining experiments and the material agency of the urban. In S. Graham \& C. McFarlane (Eds.), Infrastructural lives: Urban infrastructure in context (pp. 199-218). London and New York, NY: Routledge.

Cowley, R., \& Caprotti, F. (2019). Smart city as antiplanning in the UK. Environment and Planning D: Society and Space, 37(3), 428-448.

Davidoff, P. (1965). Advocacy and pluralism in planning. Journal of the American Institute of Planners, 31(4), 331-338.

Davidson, K., \& Gleeson, B. (2018). New Socio-ecological Imperatives for cities: Possibilities and dilemmas for Australian metropolitan governance. Urban Policy and Research, 36(2), 230-241.

du Gay, P. (2017). Introduction: Office as a vocation. European Journal of Cultural and Political Sociology, $4(2), 156-165$.

Eneqvist, E., \& Karvonen, A. (2019). Projekt och testbäddar: två alternativa vägar för hållbar stadsutveckling [Projects and testbeds: two alternatives trajectories/roads to sustainable urban development]. In J. Algehed, E. Eneqvist, C. Jensen, \& J. Lööf (Eds.), Stadsutveckling: En forskningsantologi om organiseringsutmaningar för stad och kommun [Urban development: A research anthology about organisational challenges] (pp. 77-88). Retrieved from http://www.diva-portal.org/smash/get/diva2: 1351684/FULLTEXT01.pdf 
Evans, J., \& Karvonen, A. (2014). 'Give me a laboratory and I will lower your carbon footprint!' Urban laboratories and the governance of low-carbon futures. International Journal of Urban and Regional Research, 38(2), 413-430.

Forester, J. (1989). The deliberative practitioner: Encouraging participatory planning processes. Cambridge, MA: The MIT Press.

Fred, M. (2018). Projectification: The Trojan horse of local government (Unpublished Doctoral dissertation). Lund University, Lund, Sweden.

Fredricsson, C., \& Smas, L. (2015). Tensions in Nordic urban planning. Nordregio News, 2015(2). Retrieved from http://norden.diva-portal.org/smash/ record.jsf?pid=diva2\%3A1187155\&dswid $=-3966$

Haarstad, H. (2017). Constructing the sustainable city: Examining the role of sustainability in the 'smart city' discourse. Journal of Environmental Policy \& Planning, 19(4), 423-437.

Hakkarainen, L., \& Hyysalo, S. (2016). The evolution of intermediary activities: Broadening the concept of facilitation in living labs. Technology Innovation Management Review, 6(1), 45-58.

Hall, T., \& Hubbard, P. (1998). (Eds.). The entrepreneurial city: Geographies of politics, regime and representation. Chichester: John Wiley and Sons.

Harvey, D. (1989). From managerialism to entrepreneurialism: The transformation of urban governance in late capitalism. Geografiska Annaler, 71(1), 3-14.

Healey, P. (1997). Collaborative planning: Shaping places in fragmented societies. Houndmills: Palgrave Macmillan.

Hysing, E., \& Olsson, J. (2012). Tjänstemän i politiken [Civil servant in politics]. Lund: Studentlitteratur.

Karvonen, A., Cugurullo, F., \& Caprotti, F. (2019). Introduction: Situating smart cities. In A. Karvonen, F. Cugurullo, \& F. Caprotti (Eds.), Inside smart cities. Place, politics and urban innovation (pp. 1-12). London and New York, NY: Routledge.

Karvonen, A., Evans, J., \& van Heur, B. (2014). The politics of urban experiments: Radical change or business as usual? In S. Marvin \& M. Hodson (Eds.), After sustainable cities (pp. 104-115). London: Routledge.

Kronsell, A., \& Mukhtar-Landgren, D. (2018). Experimental governance: The role of municipalities in urban living labs. European Planning Studies, 26(5), 988-1007.

Loughlin, J. (2000). Introduction: The transformation of the democratic state in western Europe. In J. Loughlin (Ed.), Subnational democracy in the European Union: Challenges and opportunities (pp. 1-33). Oxford: Oxford University Press.

Lundquist, L. (1988). Byråkratisk etik [Bureaucratic ethics]. Lund: Studentlitteratur.

Makkonen, T., Merisalo, M., \& Inkinen, T. (2018). Containers, facilitators, innovators? The role of cities and city employees in innovation activities. European Urban and Regional Studies, 25(1), 106-118.

March, J. J., \& Olsen, J. P. (2013). The logic of appropri- ateness. In M. Moran, M. Rein, \& R. E. Goodin (Eds.), The Oxford handbook of public policy. Oxford: Oxford Handbook Online. https://dx.doi.org/10.1093/ oxfordhb/9780199548453.003.0034

Marvin, S., Bulkley, H., Mai, L., McCormick, K., \& Voytenko Palgan, Y. (2018). Introduction. In S. Marvin, H. Bulkley, L. Mai, K. McCormick, \& Y. Voytenko Palgan (Eds.), Urban living labs. Experimenting with city futures (pp. 1-17). London: Routledge.

Menny, M., Voytenko Palgan, Y., \& McCormick, K. (2018). Urban living labs and the role of users in co-creation. GAIA, 26(1), 68-77.

Mukhtar-Landgren, D., Kronsell, A., Voytenko Palgan, Y., \& von Wirth, T. (2019). Municipalities as enablers in experimental climate governance. Journal of Environmental Policy and Planning, 21(6). Advance online publication. https://doi.org/10.1080/1523908X. 2019.1672525

Nadin, V. (2007). The emergence of spatial planning approach in England. Planning Practice \& Research, 22(1), 43-62.

Olesen, K. (2014). The neoliberalisation of strategic spatial planning. Planning Theory, 13(3), 288-303.

Olesen, K., \& Richardson, T. (2012). Strategic planning in transition: Contested rationalities and spatial logics in twenty-first century Danish planning experiments. European Planning Studies, 20(10), 1689-1706.

Raven, R., Sengers, F., Spaeth, P., Xie, L., Cheshmehzangi, A., \& de Jong, M. (2019). Urban experimentation and institutional arrangements. European Planning Studies, $27(2), 258-281$.

Reay, T., \& Jones, C. (2016). Qualitatively capturing institutional logics. Strategic Organization, 14(4), 441-454.

Rydin, Y. (2007). Re-examining the role of knowledge within planning theory. Planning Theory, 61(1), 52-68.

Svara, J. H. (2006). Introduction: Politicians and administrators in the political process-A review of themes and issues in the literature. International Journal of Public Administration, 29(12), 953-976.

Thornton, P., \& Ocasio, W. (2008). Institutional logics. In R. Greenwood, C. Oliver, K. Sahlin, \& R. Suddaby (Eds.), Handbook of organizational institutionalism (pp. 99-128). Newcastle upon Tyne: Sage.

von Wirth, T., Fuenfschilling, L., Frantzekaki, N., \& Coenen, L. (2019). Impacts of urban living labs on sustainability transitions: Mechanisms and strategies for systemic change through experimentation. European Planning Studies, 27(2), 229-257.

Voytenko Palgan, Y., McCormick, K., \& Evans, J. (2018). Urban living labs: Catalysing low car bon and sustainable cities in Europe. In S. Marvin, H. Bulkley, L. Mai, K. McCormick, Y. Voytenko Palgan (Eds.), Urban living labs. Experimenting with city futures (pp. 21-36). London: Routledge.

Yin, R. (2014). Case study research: Design and methods. Newcastle upon Tyne: Sage. 


\section{About the Authors}

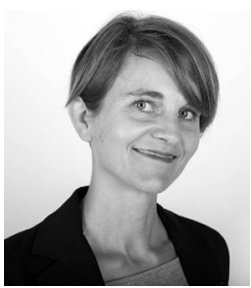

Lina Berglund-Snodgrass is a Researcher and Senior Lecturer in Spatial Planning at Blekinge Institute of Technology. Her research concerns ideas, roles and knowledge in planning. She is currently involved in research projects that address questions of changing roles for urban planning in urban testbeds and experiments as well as political dimensions of organising strategic and collaborative planning.



Dalia Mukhtar-Landgren is a Researcher and Senior Lecturer at the Department of political science at Lund University in Sweden. Her research includes new forms of urban planning and development, including issues such as projectification, experimentation and innovation work. She is currently engaged in research projects on testbed planning, urban experimentation, smart mobility and processes of local innovation and development practices. 